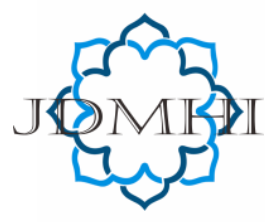

email: jdmhi@walisongo.ac.id

Journal of Digital Marketing and Halal Industry

ISSN: 2716-4810 (print) ISSN: 2716-4802 (online)

\title{
Halal Branding; A Religious Doctrine in the Development of Islamic Da'wah
}

\author{
Abdul Rachman \\ STES Islamic Village Tangerang, Banten, Indonesia
}

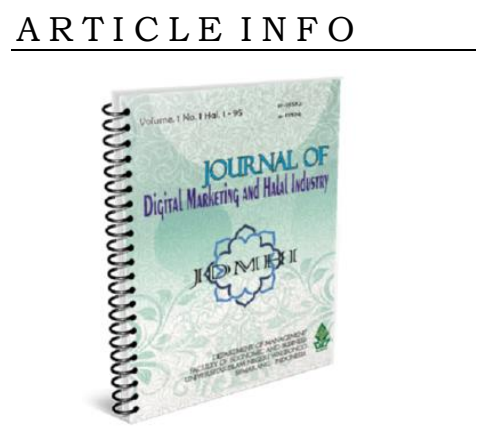

Article history:

Received 28 July 2020

Accepted 21 October 2020

Published 30 October 2020

Keywords:

Halal, Doctrine, Da'wah

\section{A B S T R A C T}

Halal Branding has become a trend and will continue to grow. Halal Branding is implemented in almost all fields, especially food, medicine, cosmetics, fashion, and even tourism. Muslims use halal Branding as a guarantee of consuming a product to avoid sins. Meanwhile, Halal Branding is used by non-Muslims, one of which is for business and consumption purposes. Halal Branding not only guarantees the product is healthy and safe but also as Islamic religious doctrine. This study aims to determine how much Halal Branding is trying to ground the halal concept as the best concept in the halal lifestyle. Another objective is to observe various approaches in developing Halal Branding so that the existence of Halal Branding as a religious doctrine can become a medium for preaching to all groups, including nonMuslims, so that the acceleration of the development of Islamic da'wah will be more aggressive. This paper is expected to be used as knowledge and development of halal in life aspects to be appropriately implemented. Research results show that halal Branding indirectly into religious doctrine on halal products and become a useful tool of Islamic da'wah.

@2020 Journal of Digital Marketing and Halal Industry

\section{Introduction}

Islam as another religion of rahmatan lil'alam must have its benefits for all humanity, including non-Muslims. Non-Muslims have the right to receive fair treatment in their state life (Mubarok \& Imam, 2020). Religious tolerance is essential in the Indonesian State framework, which has Pancasila and the 1945 Constitution. The cycle of state life always has social friction, which leads to religious conflict. Therefore, it is necessary to have a two-way dialogue that must be developed and

\footnotetext{
* Corresponding author. email: abdulrachman@stes.ac.id DOI: http://dx.doi.org/10.21580/jdmhi.2020.2.2.6149
} 
used as a routine schedule in building communication between religious communities (Aini et al., 2020).

Indonesia is the country with the largest Muslim population globally, namely $190,113,060$ of $237,641,326$ people or $80 \%$ (BPS, 2013). While the world population (2013) is 7,021,836,029. The distribution according to religion is: Islam $22.43 \%$, Catholic Christian 16.83\%, Protestant Christian 6.08\%, Orthodox 4.03\%, Anglican 1.26\%, Hindu 13.78\%, Buddhist 7.13\%, Sikh $0.36 \%$, Jewish 0.21\%, Baha'i 0.11\%, Others $11.17 \%$, Non Religion 9.42\%, and Atheists 2.04\% (Ruslan, 2004). Even the prediction of the United States research institute Pew Research Center states that Islam will become the largest religion in the world by 2075 (BCC News Indonesia, 2017). This indicates that the Muslims' population in the world will be the largest to affect the Muslim community. As the largest religion in the world, Islam is unique in all aspects of life. Islam does not only talk about prayer, fasting, zakat, and so on. Islam also talks about life from the law, psychology, politics, culture, society, and even economics (Majid, 2016). In economic matters, since the beginning, Islam has presented various kinds of contracts in business, such as mudharabah, murabahah, musyarakah, rahn, takaful, etc, adopted in the world of Islamic banking and finance. Likewise, in muamalah, Islam has already explained Muslims' obligation to eat halal and tayyib (good) food. This order has existed since the Quran was revealed to the Prophet Muhammad.

As the holy book of Muslims, the Koran explains many things about halal and haram. Al-Quran also tells all humanity not to consume haram products such as carcasses, pork, blood, etc. It is even haram if finishing haram products. Al-Quran gives a lesson on how important it is to live with something halal. How vital the right product is. This is how great the Al-Quran talks about halal. It has become commonplace for Muslims to consume halal products because it has become a doctrine. The doctrine taught in the Koran is a religious doctrine that must be worked out (Amalia, 2019).

Along with the times, Halal is needed by all groups, including non-Muslims. Halal appears on Muslim minority countries such as America, Canada, South Korea, Japan, Taiwan, New Zealand, the Netherlands, Australia, etc. Halal is used in food products, cosmetics, medicine, fashion, and even tourism. The benefits of the Halal concept have been felt by all groups, both in the health and business sectors. Therefore, many products have Halal brand. A halal brand can make a product more special than a product that does not have a halal brand. To get halal, producers must certify their products to get a halal label from a halal certification body, such as LPPOM MUI. LPPOM-MUI Director Lukmanul Hakim said that in the future halal certificates will increasingly become a necessity for producers and consumers so that more producers will apply for halal certificates. Products that have a halal certification have relatively high selling points because, currently, halal products are a trend in trade (Burlian, 2014).

Many halal labels are increasingly faked so that many products are not certified halal by halal certification bodies, but halal titles are listed illegally (Nadhifah \& Adinugraha, 2020). This certainly makes consumers disappointed. 
Therefore, the researcher considers that halal is a label and a "brand" because if it is only a label, what is visible is only the outer part of the product. It is different if halal has become the Branding of each product, then the outside and inside can feel the halalness of the product. Therefore, in addition to being a religious doctrine, halal Branding can be a medium for da'wah in the development of preaching. According to the Director of the LPPOM-MUI at the WHFC Annual Session, halal provisions were not just objects that were considered frightening and burdensome but should be an added value for the business world. In the halal aspect, universal values, such as quality, food safety, and health, are very much needed by consumers, not only Muslims but also humanity in general.

The opportunities and potentials of halal in several Asian, European, and American countries can be utilized to spread Islamic da'wah because halal has been a patent right of Muslims since the very beginning. Of course, the development of the concept of halal in all products will raise the Islamic religious doctrine of halal. This is proof that Islam is a religion that can benefit all people. So that Islamic da'wah can be channelled more elegantly and effectively. Halal law on food, in Islam, is not just a religious doctrine but guarantees that food is healthy and safe, which scientifically makes sense (Twaigery: 1989). This is what underlies that halal in Islam is beneficial for all circles.

In the development of da'wah, many media of preaching have transformed. Da'wah media will continue to metamorphose according to the needs of the times. In an era of technology like today, da'wah media can collaborate with the latest technology. One form of preaching media that is currently proliferating and becoming a trend is Halal Branding media. Supporting and implementing Halal Branding in all aspects of life such as Halal Lifestyle, Halal Tourism, Halal Food, Halal Fashion, and so on will make halal a brand for one's life. Halal Branding will carry the fragrant name of Islam. Halal Branding can also provide doctrine to all circles so that everyone's delivery of Islamic da'wah will be felt. Based on the things that have been disclosed above, it is deemed necessary to explain more about the concept of Halal Branding based on the provisions and regulations in Indonesia.

\section{Literature Review}

\section{Halal Branding; Elegant and Effective Da'wah Model}

In its meaning, Halal in Arabic comes from the root word اللى (الإباة) loose or not bound or something that is allowed according to the Shari'ah. In the fiqh dictionary, the term halal is understood as everything that can be done or eaten. This understanding is generally related to food and beverage problems. Contemporary scholar Yusuf al-Qaradhawî defined halal as something with which a loose knot is untied, and God allows it to be done. In terms, it means everything that is not subject to its use sanction or an act that is exempt from the Shari'ah to do.

The above definitions give the impression that halal can be done and will not get in. Halal, according to Prof.Dr. K.H. Ali Mustofa Ya'kub, MA in food or beverage products is when it meets some of the criteria below, namely; 
1. The food and drink is tayyib (good), which is felt delicious by the senses or soul is not painful and disgusting.

2. Does not contain dharar (danger);

3. Does not contain feces;

4. Not intoxicating and

5. It Does not have human body organs.

The Ministry of Religion of the Republic of Indonesia defines that halal products are products that meet the requirements of halal following Islamic law, namely:

1. It Does not contain pork and ingredients derived from pork.

2. It Does not contain banned substances such as substances derived from human organs, blood, feces, etc.

3. All ingredients derived from halal animals are slaughtered according to Islamic sharia procedures.

4. All storage, sales, processing, management, and transportation facilities shall not be used for pigs. If it has been used for pigs or other nonhalal goods, it must first be cleaned with procedures set according to Islamic law.

5. All foods and beverages that do not contain alcohol

The conclusion from several views on halal is that halal is a religious doctrine that has good and healthy values. If someone consumes something lawful, he will receive healthy benefits, avoid harm, be far from a sin, and even feel the pleasure of a product from the perspective of the five senses and the soul. The command to consume something halal is mandatory. This has been explained in the Koran. In his speech to the conference entitled International Halal Standard: Make the Frontier Global Trade in the Annual Session of the World Halal Food Council (WHFC) in Jakarta on January 17, 2012, the Chairman of MUI, KH. Amidhan stated that the halal provisions are not only a provision that applies to Muslims only in a limited manner but also as a necessity for humanity as hinted by Allah SWT. in the Koran, which commands humankind to consume products/foods that are halal.

Believers! eat of the good things we have given you and give Allah thanks if ye worship Him only. (QS. Al-Baqarah, 2: 172)

The concept of halal can be viewed from two perspectives (Che-Man: 2008). The first is a religious perspective, namely as a food law so that Muslim consumers can eat food according to their beliefs. This brings the consequences of consumer protection. The second is an industry perspective. For food producers, this halal concept can be captured as a business opportunity. For the food industry, whose target consumers are mostly Muslims, of course, the guarantee of the halalness of the product will increase its value in the form of intangible value. Food products whose packaging includes a halal label will increase the attractiveness of Muslim consumers. One important aspect that marks the rise of business ethics among companies (producers) is the rise of food products with halal labels. Even consuming halal products is included in Islamic economics, namely, consumption, which is controlled by five basic principles, namely: the Principle of Justice, the Principle of Cleanliness, the Principle of Simplicity, the Principle of Generosity, and the Principle of Morality.

Through the concept of halal, Islamic values 
will be felt by all humanity. Halal Branding can be an icon in an elegant and practical preaching media because halal Branding contains many benefits, including consuming halal products; it will get health. By consuming halal products, you will avoid sins. Using halal products, you will get material benefits because halal Branding is an attraction in product sales. By including halal on the product, the product has clear legal legality. Producing halal products is included as part of consumer protection services that have been protected in the Consumer Protection Law (UUPK) Number 8 of 1999. Halal standards in Islam are not the same as quality standards. Quality standards are prepared and set by the manufacturer. This determination is based on consumer demand or need. It is different from the Halal Standards made and stipulated by Allah SWT through the Al-Quran and Hadith and ijtihad, which are interpreted by people who have the authority to do so (ulama).

Burlian explains that from a normative religious point of view, it is clear that Muslims are required to consume halal food, not forbidden or unclean food. Second, from the juridical side. The MUI halal certificate is a morale booster and provision with high binding power for economic and business actors, especially Muslims. Third, sociologically. In this perspective, there is a tendency in society to see halal certification as a binding legal instrument for economic actors, especially Muslims. And this will result in a social movement that is sociologically high enough to protect consumers from products prohibited by Islamic law.

Halal Branding is a religious doctrine and a means of preaching for all groups, especially in countries with Muslim minorities such as Japan, South Korea, Singapore, America, Australia, the Netherlands, New Zealand, and others. So. Halal Branding is a media of preaching that can be categorized as an elegant and effective da'wah medium. This consideration is based on the fact that Halal Branding is a brand that has apparent legal legitimacy with excellent and healthy values. Halal Branding also contains selling points in selling a product. Furthermore, Halal Branding is an attraction in promoting a product because consumer interest in halal products is very high. On this basis, what makes Halal Branding very useful in developing Islamic teachings throughout society.

\section{Regulation on Halal Branding}

By producing halal products, producers are protected by regulations that have been regulated in the Consumer Protection Law (UUPK) Number 8 of 1999, which confirms that consumer protection is held as a joint effort based on five relevant principles in development, namely: the principle of benefit, fairness, balance, consumer safety and security, and legal certainty. Halal has a code of use for consumers who consume it, namely healthy and good. Halal also contains justice in the products consumed because you get the right information according to the raw materials' composition by consuming these products. Halal also maintains the safety and security of consumers in consuming a product.

Based on Law No. 18 of 2012, Law No. 8 of 1999, and Government Regulation No. 69 of 1999, as well as the Decree of the Minister of Religion Number 518 of 2001, then the halal industry, which was regulated initially only in fiqh, has now been regulated in government 
laws and regulations. Thus there is a new paradigm in the regulation of halal products. This is extraordinary progress that many regulations have controlled and maintained the halal quality of a product to protect and safety. With this law's existence, halal products become an obligation for producers to pay attention to the halal side. There are no more illegal halal labels or counterfeiting halal labelling on a product.

During its development, there are several examples of cases that have made Muslim consumers in Indonesia nervous, which in the end caused considerable losses to producers and the business world, namely: the case of the issue of lard (1988), the chance of wild boar meat on the market (2000-2002), the point of Ajinomoto flavouring food (2001), the case of beef jerky mixed with pork in West Java and East Java (2009) and the issue of pilgrims' meningitis vaccine containing pork enzymes (2009). Muslim consumers boycott products that are known or declared illegal, causing producers to suffer heavy losses. The development of food technology enables the production of packaged food in large quantities and has a relatively long shelf life. This case clearly illustrates that the legalization of halal in a product has a positive impact. Still, on the other hand, the illegalization of a product will harm both consumers and producers.

Based on Law no. 18 of 2009 in pasal 58, which states that the Government and Regional Governments following their respective powers carry out supervision, examination, testing, standardization, certification, and registration to ensure safety, health, integrity, and registration. It is then known as the Halal Assurance System (SJH), a system that describes, connects, accommodates, and integrates Islamic legal concepts, especially those related to halal and haram, business ethics and management, planning procedures, and mechanisms, and implementation. And evaluation in the production chain. Or processed materials to be consumed by Muslims. Law (UU) No. 33/2014 on Halal Product Guarantee explains that there is an obligation to be certified halal for products circulating and traded in Indonesia's territory, which takes effect five years after the Halal Product Guarantee Law was enacted. According to Law no. 33 of 2014 products that have been declared halal according to Islamic law, such as food, beverages, medicines, cosmetics, chemical, biological, genetic engineering products, and consumer goods that are used and utilized. Public. This law can protect Muslim consumers from consuming a product. The halal guarantee is an obligation. The halal contract is security and comfort. A halal guarantee is a health. According to the Secretary-General of the Ministry of Trade, Nur Syam, halal certification aims to create a guaranteed quality product that is guaranteed for its health and halalness. Also, halal certification can increase added value for traded products.

The existence of regulations regarding the halal certification of a product, be it food, medicine, or cosmetics, is part of protecting consumers, especially those who are Muslim. Islam itself, in its teachings, is ordered to consume halal products. In terms of food and goods, Muslims are instructed to eat and use suitable, holy, and clean materials. Muslims' cleanliness, purity, and good or bad food and 
goods are always related to halal and haram laws. Therefore, the existence of Halal Branding regulations is perfect for ensuring consumer protection in consuming halal products.

\section{Halal Certification Agency as an Islamic Da'wah Institution}

Halal Branding for a product must pass through halal certification carried out by the Halal Certification Agency in a country. Halal certification is a process that must be carried out for business people or producers to be able to produce halal products. For that, several mechanisms must be carried out by business people. However, there is some standardization of halal certification bodies not recognized by halal certification bodies in other countries. This is because it is different in terms of assessment standards. Therefore, to equalize the standardization of halal product assessment, there is a need for mutual agreement in standard operating procedures in researching, analyzing, and assessing to be recognized by all halal certification bodies in the world.

In carrying out halal certification, the quality or standard of Indonesian halal certification becomes a reference for halal labelling institutions or institutions globally. There are 42 halal certification bodies recognized by the Indonesian Ulema Council from 23 countries. The following are some of the world standardization institutions recognized by the Indonesian Ulema Council, namely the Singapore Islamic Council, the Malaysian Islamic Advancement Position (JAKIM), the Office of Muslim Affairs (OMA) Philippines, The Central Islamic Committee of Thailand (CICOT) Thailand, the Taiwan Halal Integrity Development Association ( THIDA), Jamiat
Ulama E-Maharashtra (JUM) India, Muslim Professional Japan Association (MPJA), The Islamic Coordinating Council of Victoria (ICCV) Australia, Dutch Halal Quality Control, UK Halal Food Authority (HFA), and Halal Food Council USA (HFC USA).

In carrying out halal certification there are differences between several countries. This difference, for example, in Indonesia carries out centralized halal labeling at the Indonesian Ulema Council (MUI), in other countries halal certification can be issued by companies that have the authority. In France there are several institutions, namely A Votre Service (AVS), Muslim Conseil International (MCI), L'association De Contrôle Et De Certification Des Produits Halal Agrée (KARAMA), le Groupement Islamique des Sacrificateurs et Contrôleurs Musulmans (GISCOM), 1 'Association Finistérienne pour la Culture Arabo-Islamique (AFCAI), Malaysia Halal Certificate (MIHAS), le Bureau de Contrôle de l'Alimentation et de l'Authentification Religieuse (BCAAR), and the United States Halal Certification Institute (IFANCA). Furthermore, Australia with six institutions, New Zealand with three institutions, the Netherlands with three institutions, America with seven institutions, and Brazil and Japan, each with two halal labelling agencies.

This illustrates a common perception and standardization in halal certification so that the assessment of halal values has become a standard agreement in both Muslim-majority countries and Muslim minorities. This means that there is togetherness in carrying out the da'wah values that exist in Halal Branding. Every institution engaged in halal certification can also act as an Islamic missionary institution for all groups, including non- 
Muslims. The background of the establishment of halal certification bodies in America, Canada, Germany, and the Netherlands are two things: the da'wah of Islam. It is protected from consuming unlawful foodstuffs and maintaining Muslims' Islamic faith in this Muslim minority country. Despite the lack of fiqh experts in the country, halal certification bodies in America, Canada, Germany, and the Netherlands have established cooperative relationships with other institutions at the international level, such as establishing relationships with the Indonesian Ulema Council, especially with the Indonesian Ulema Council LPPOM.

\section{The Method, Data, and Analysis}

In conducting this research, researchers used a descriptive type of research. Descriptive Analysis is a research method intended to describe existing phenomena, which are taking place now or in the past. This study does not manipulate or change the independent variables but describes a condition as it is. Depiction of conditions can be individual or use numbers (Sukmadinata, 2006). The Data uses secondary sources, namely fatwas, research results, laws and regulations, decrees, news, books, brochures, booklets, documentation, and relevant literature. This study aims to ground the concept of halal as the best concept in the halal lifestyle. Also, to observe various approaches in developing Halal Branding so that the existence of Halal Branding as a religious doctrine can become a medium for preaching to all groups, including non-Muslims, so that the acceleration of the development of Islamic da'wah will be more aggressive.

\section{Result and Discussion}

Halal Branding can be a business icon that is used by all groups. Opportunities and potential for halal products are currently increasing so that the phenomenon of Halal Branding is powerful in both Muslim majority and Muslim minority countries, such as Japan, South Korea, America, New Zealand, and so on. Halal Branding has penetrated various groups without realizing it or not because it has become a trend and lifestyle. This phenomenon is very beneficial for Muslims because basically, Halal Branding is a patent right for Islam. Even halal Branding has been around for a long time by becoming a religious doctrine. Muslims must consume halal products because when using halal products, they will avoid sins. This is a logical consequence for adherents of Islam. However, the concept of Halal Branding has been adopted by many groups, making it easier to disseminate Islamic teachings and understanding to all circles. This is very effective and elegant in preaching Islam so that the development of Islamic da'wah can be more aggressive and touched the heart of every human being. It is a hope that if more people consume halal products, may Allah SWT guide many people to become part of Islam's adherents. By making halal a lifestyle, halal becomes a beneficial religious doctrine for all Muslims and non-Muslims.

Products labelled halal has gone through a series of rigorous tests and trials conducted by LPPOM MUI or currently BPJPH. This product can be ascertained that it does not contain haram ingredients, unclean materials, and unqualified ingredients but contains safe and guaranteed and quality raw materials and 
can provide health benefits. Halal products are products that are free from those that are haram according to Islam. The production process must also be halal, meaning that they are not contaminated with haram ingredients. The production process consistently maintains the halalness of materials and production processes. Since Law Number 33 of 2014, almost all products have been certified halal by LPPOM MUI. Examples of products such as detergents, electronics, sanitary napkins, diapers, refrigerators, milk bottles and nipples, and other products. It is interesting, indeed that the growth of halal certification has increased every year. However, some products should not be certified halal but certified halal, such as refrigerators, microwave ovens, and others. Even the Deputy Director of LPPOM MUI, Sumunar Jati, said no provision required electronic goods to obtain halal certification. However, LPPOM MUI also cannot refuse the certificate request. This image shows that Halal Labelization is an added value for a product, and halal is identical to being clean, safe, and fair.

MUI Halal certification for food products, medicines, cosmetics, and other products is carried out to provide certainty for their halal status to reassure consumers in consuming them. The producer also guarantees the continuity of the halal production process by implementing the Halal Assurance System. Thus, some several policies and procedures have been taken to obtain halal certification by the LPPOM-MUI even though the actual authority currently lies with BPJPH. However, LPPOM is still needed by collaborating with $\mathrm{BPJPH}$. Below are the procedures and policies set by the LPPOM-MUI in regulating the halal certification of a product. In general, the Halal Certification Procedure is as follows:
1) Companies that apply for certification, new registration, development (product/facility), an extension can register online. Through the LPPOM MUI website (www.halalmui.org) or directly to the website: www.e-lppommui.org.

2) Fill in the registration data: certification status (new / development/renewal), halal certificate data, HAS status (if any), and product group.

3) Paying the registration fee and halal certification contract fee through the LPPOM MUI Treasurer by email: bendaharalppom@halalmui.org._The components of the halal certification contract costs include: audit fees, halal certificate fees, HAS implementation assessment costs, Halal journal publication costs. These costs exclude transportation and accommodation that are borne by the company.

4) Fill in the required documents according to the registration status (new, development, or renewal), and business processes (processing industry, slaughterhouse, restaurant and service industry), HAS manual, production process flow diagram, factory data, products, materials, and documents of the materials used, as well as the product matrix.

5) After completing the required documents, the next step is according to the halal certification process flow chart above, namely checking the adequacy of documents - Halal Certificate Issuance. 
Figure 1, Halal Certification Process

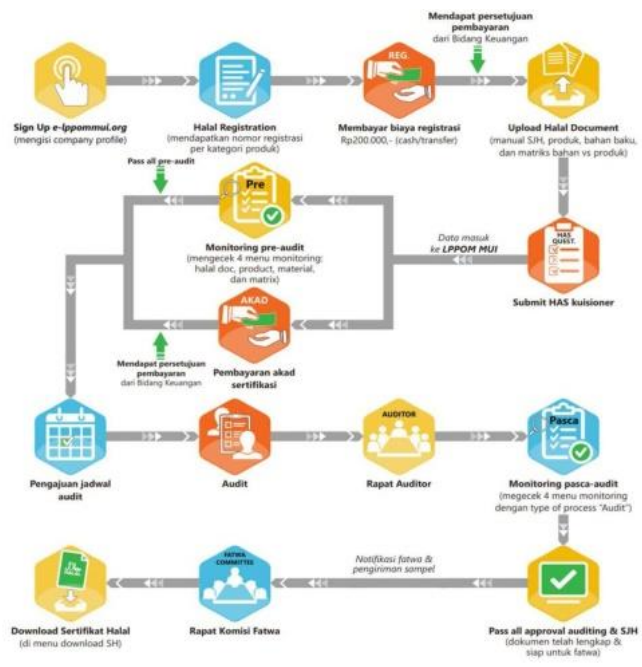

Source: halalmui.org

Transformation of Islamic Da'wah Media

In Arabic, da'wah is in the form of a verbal noun. The verb is $( \pm 2)$ has the meaning of calling, inviting, or calling. The word da'wah can mean prayer, cry, scream, invitation, request an invitation. This meaning is explained in the Al-Munawwir ArabicIndonesian dictionary. Meanwhile, in the Big Indonesian Dictionary, Da'wah is defined as broadcasting, propaganda, broadcasting religion in the community and its development, the call to embrace, study and practice religious teachings. Some of the definitions above are definitions in language that have global interpretations of meaning. However, the essence of a da'wah is to invite or call to learn religious teaching.

According to Hasanudin, Islamic preaching means inviting or calling to do good and prevent evil. Change people's behaviour for the better, to realize comprehensive Islamic teachings. Society as the whole system of living together in the framework of human development. Likewise with HM Arifin, giving an explanation of da'wah, which contains the meaning as an activity both in oral, written, behaviour, and so on which is carried out consciously and planned to influence others both individually and in groups, to arise in him an understanding. , awareness, appreciation, and practice of religious teachings as massage conveyed to him in the presence of coercive elements.

The explanation about da'wah above is an effort to influence and invite others to realize Islamic teachings in everyday life. Da'wah can be applied in grounding Halal Branding to all circles, both Muslim and non-Muslim, both in Indonesia and in the world. Dropping the concept of halal in all aspects of life can be an effective medium in developing Islamic da'wah. This indicates that there is information about the press of preaching being carried out at this time. The media of preaching, which is always carried out by lectures or sermons, is transformed into the consumption aspect. This is very good because the essence of proselytizing the concept of halal is the doctrine of the Islamic religion, namely that halal is a patent right for Islam, halal is the legitimacy of goodness, halal is the labelling of quality and competitive products. Da'wah with Halal Branding media can be more aggressive in touching the heart of every human being because you can directly feel the benefits of halal itself.

Halal Branding can be an attraction for a product. By using halal labelling, it will add value to a product. It will fulfil the elements of guarantee of protection and legal certainty of food for consumers by producing halal products. It is necessary to formulate a 
promise of safety and legal certainty for the halal food sector. First, the philosophical foundation, for Muslims, consuming food and other products is not just for fulfilling physical needs. Still, there are other, more important goals, namely worship and proof of obedience to Allah SWT by upholding Islamic teachings through the disclosure of maqâshid al-syarî'ah. Second, the sociological basis. The position of the Indonesian Muslim community is that they are the largest consumers of food and other products. They have constitutional rights to obtain legal protection for food and other products following their religious beliefs. Therefore they need to be given legal guardian in the form of guarantees of the halalness of the food they consume and other products used.

Also, Halal Branding is a strength because there are already regulations that regulate it, such as Law Number 33 of 2014 concerning Halal Product Guarantee. The law governs the halal certification of a product, be it food, medicine, or cosmetics. The law was made as part of the protection of consumers, especially those who are Muslim. The existence of this law provides legal certainty for the halalness of a product as proven by a Halal Certificate. Islam itself, in its teachings, is ordered to consume halal products. In terms of food and goods, Muslims are instructed to eat and use suitable, holy, and clean materials. Muslims' cleanliness, purity and good or bad food and goods are always related to halal and haram laws. Therefore, the existence of regulations about Halal Branding is excellent to ensure consumer protection in consuming halal products. Thus, the religious doctrine of Halal is one way of developing Islamic da'wah. Islam is very concerned about cleanliness, hygiene, purity, and even benefits. If you eat halal products, your life will be healthy. Eating halal products can be used as a lifestyle.

\section{Conclusion}

Halal products have become part of the lifestyle of the Indonesian people and even the world. To achieve halal labeling, it requires a halal certification that has been established by the government. Halal certification is considered as one of the highest guarantees for the safety level of a product and to avoid raw materials that are haram, unclean. The production process is guaranteed to be halal. Halal is not only related to what is consumed but also the tools used. Halal Branding is currently a necessity and lifestyle for every human being. Even the development of Halal Branding will continue to develop in not only Indonesia but also in the world, even some developed countries in Asia, Europe, and America have produced halal products, especially in the food sector. Halal Branding assures that the product is safe, good, and clean. However, Halal Branding indirectly becomes an Islamic religious doctrine because Muslims use halal Branding as a guarantee of consuming a product to avoid sins. Meanwhile, Halal Branding is used by nonMuslims, one of which is for business and consumption purposes.

\section{Recommendation}

Halal Branding becomes a useful da'wah tool for all groups, including non-Muslims.

\section{References}

Aini, N., Ardiani, F., \& Hanastiana, M. R. (2020). Halal Food Industry: Challenges 
And Opportunities In Europe. Journal of Digital Marketing and Halal Industry, 2(1), 43-54.

Amalia, F. (2019). The Role of Religiosity on Halal Product Purchasing Decision Case Study: Wardah Cosmetics. 19-25.

BCC News Indonesia. (2017). Islam akan menjadi "agama terbesar" pada 2075. Retrieved from http://www.bbc.com/indonesia/majalah39510081

Burlian, P. (2014). Reformulasi Yuridis Pengaturan Produk Pangan Halal. Ahkam, XIV(1).

Depdikbud. (1988). Kamus Besar Bahasa Indonesia. Jakarta: Depdikbud.

Fauziah. (2012). Perilaku Komunitas Muslim dalam Mengonsumsi Produk Halal di Provinsi Bali. Jurnal Multikultural \& Multireligius, 11(2), 142-155.

Kasdi, A. (2013). Tafsir ayat-ayat konsumsi dan implikasinya terhadap pengembangan ekonomi islam. Equilibrium, 1(1).

LPPOM MUI. (2020). Persyaratan Sertifikasi Halal MUI. Retrieved from https://www.halalmui.org/mui14/main/ page/persyaratan-sertifikasi-halal-mui

Majid, Z. A. (2016). Ekonomi Dalam Perspektif Alquran. Ahkam, XVI(2).

Mubarok, F. K., \& Imam, M. K. (2020). Halal Industry in Indonesia; Challenges and Opportunities. Journal of Digital Marketing and Halal Industry, 2(1), 55-64.

Munawwir, A. . (1984). Kamus al-Munawir Arab-Indonesia. Yogyakarta: Pondok Pesantren al-Munawwir.

Nadhifah, H. H., \& Adinugraha, H. H.
(2020). Analysis of Factors influencing the Purchasing Decision of Facial Foam labeled Halal. Journal of Digital Marketing and Halal Industry, 2(1), 65-80.

Priherdityo, E. (2015). Jaminan Halal dari Luar Negeri Sama Dengan Halal dari MUI? Retrieved from https://www.cnnindonesia.com/gayahidup/20151017100852-26285453/jaminan-halal-dari-luar-negerisama-dengan-halal-dari-mui/

Ramlan, R., \& Nahrowi, N. (2014). Sertifikasi Halal Sebagai Penerapan Etika Bisnis Islami Dalam Upaya Perlindungan Bagi Konsumen Muslim. AHKAM: Jurnal Ilmu Syariah, 17(1), 145-154. https://doi.org/10.15408/ajis.v17i1.125 1

Ruslan, H. (2004). Hari Ini, Islam Jadi Agama Terbesar di Dunia. Retrieved from http://www.republika.co.id/berita/dunia -islam/hikmah/14/01/13/mzbetu-hariini-islam-jadi-agama-terbesar-di-dunia

Sugiyono. (2012). Metodologi Penelitian Kualitatif Kuantitatif dan R\&D. Bandung: Alfabeta.

Undang-Undang Nomor 8 Tahun 1999. Undang - Undang Perlindungan Konsumen (1999).

Yaqub, A. M. (2009). Kriteria Halal Haram, untuk pangan, obat, dan kosmetika menurut Al-Quran dan Hadis. Jakarta: PT. Pustaka Firdaus. 